\title{
THE EFFECT OF SAVING AND CAPITAL EXPANSION ON FINANCIAL AND TECHNOLOGICAL DEVELOPMENT IN GCC COUNTRIES
}

\author{
Faris ALSHUBIRI \\ Department of Finance and Economics, College of Commerce and Business Administration, \\ Dhofar University, Salalah, Oman
}

Received 23 October 2020; accepted 04 July 2021; first published online 15 November 2021

\begin{abstract}
This study examined the effect of the relationship between saving and capital expansion on financial and technological development in three GCC countries using panel data from 1990 to 2019. The study used panel least squares, feasible general least squares, dynamic ordinary least squares and fully modified ordinary least squares used in the study. The findings showed that there was a significant positive long-run relationship between capital expansion and financial development and was a positive and insignificant long-run relationship between saving and financial development. Conversely, the study showed that there was a significant positive long-run relationship between saving and technological development. Meanwhile, there was a negative long-run relationship between capital expansion and technological development. Pairwise Granger causality test results showed that there was bidirectional causality between saving and financial development, a single causal direction from Adjusted net national income and financial development and a single causal direction from technological development and saving and Inflation, consumer prices. The main conclusions of the study were saving tends to support technological development, while investment tends to improve financial development. Therefore, GCC countries should formulate a long-term growth strategy in all sectors to determine their development requirements in light of the available resources.
\end{abstract}

Keywords: capital expansion, saving, economic growth theory, financial development, technological development, panel cointegration.

JEL Classification: G24, G41, F63, B26, B41, O31.

\section{Introduction}

The importance of saving in emerging countries depends on the ability of the country to select and follow the appropriate model to activate the investment function so that the proportion of national saving is maintained through reliance on available investment restrictions (Arndt, 1991). Growth theory indicates that financial development depends on savings

*Corresponding author. E-mail: falshubiri@du.edu.om

Copyright (c) 2021 The Author(s). Published by Vilnius Gediminas Technical University

This is an Open Access article distributed under the terms of the Creative Commons Attribution License (http://creativecommons. org/licenses/by/4.0/), which permits unrestricted use, distribution, and reproduction in any medium, provided the original author and source are credited. 
ratios and that the ability to increase saving and capital expansion depends on the level of technology used (Singh, 2009; Solow, 1988). The success of the savings contribution to financial development depends on how long a country can exploit its production resources by increasing the amount of capital and assets used in the production process (Mason, 1988; Dermirguc-Kunt, 2006; Chao et al., 2019).

In this view, the importance of saving is closely related to the characteristics of the Gulf Cooperation Council (GCC) countries. Since they have oil and natural gas resources, these countries can obtain savings ratios in order to achieve economic wealth more easily than surrounding countries. The presence of wealth and economic resources in the GCC countries enhances foreign investment and requires the optimal use of resources. In addition, increased capital expansion efficiency helps enhance capital and alleviate resource scarcity. The majority of countries saving is not directly reflected in financial development, as many countries that are poor in economic resources are working to creating investments to create an environment for investments and thus enhance the saving processes for various productive sectors. Therefore, saving is more sensitive to the necessity of adapting to technology, and it may be reflected in financial development (Aghion et al., 2016).

Financial development in the GCC countries has led to noticeable gross domestic product (GDP) development GDP increased by 7\% in 2019 compared to a $2 \%$ increase in 2018 . However, economic growth seemed to recover with the economic diversification and environmental sustainability challenges faced by the GCC countries, so that investment increased, and climate resilience was considered.

Country-level differences in economic wealth and income exacerbate the differences between rich and poor countries, and these differences exceed the savings ratios between them. In fact, (World Bank, 2019) have shown that middle income countries have Higher rates of saving than high income countries, leading to the following question: Can GCC countries increase the growth of saving or capital expansion? To answer this question, it is necessary to diagnose the relationship between saving, capital expansion and financial development.

Specifically, the present study analysed on how the relationship between these two factors affected financial and technological development through the lens of economic growth theory. Neoclassical theory indicates that saving plays a prominent role in investment in order to enhance financial development. Ramsey (1928) explained that saving models are in line with economic theory while saving models are not in line with early-stage neoclassical models; this matter reinforces the need to create saving behaviour that is in line with the economic growth model through increased investment (Bebczuk, 2000)..

Savings ratios a basic factor in the economic growth model and are determined by maximising the levels of consumption and interaction between markets. Meanwhile, technological changes have become a necessity and another important determinant of economic growth, and human capital has been added to the capital considered in the economic growth equation (Mankiw et al., 1992; Attanasio et al., 2000; Aghion et al., 2009).

Many studies have linked the relationship between saving that brings in investments and its effect on technological growth through international trade and the importing of technological products (Coe \& Helpman, 1995; Coe et al., 1997; Kwark \& Shyn, 2006). Imported technology contributes to technological development and adapts to it in light of the presence 
of strong capital working to regulate foreign trade (Kwark \& Shyn, 2006; Park, 2004; Le, 2008; Le \& Bodman, 2011). Bodman and Le (2013) pointed out that technology enhances productivity and has a direct impact on foreign investment due to the strengthening of research and development processes and manpower training. Technology transfer and development occurs through knowledge sharing between countries, economic freedom and capital stock trading, which enhance market strength. Likewise, freedoms in foreign investment enhance international production and increase foreign capital, which, in turn, improves the economic growth of the host countries (Hansen \& Rand, 2006). In recent years, GCC countries have sought to conduct an industrial, economic and financial revolution that is compatible with the global competitiveness index and the goals of sustainable development.

According to the literature (e.g., Coe \& Helpman, 1995; Coe et al., 1997; Kwark \& Shyn, 2006; Attanasio et al., 2000; Aghion et al., 2009) the effect of saving and capital expansion on technological and financial development has not been sufficiently researched. Although some studies have examined the relationship between saving and capital expansion in terms of technological or financial development, there is a research gap in linking the two components and studying the effect of the relationship of these variables on technological and financial development. This study aimed to address this gap. Furthermore, to the best of our knowledge, the current study is one of the first studies to examine economic growth theory in GCC countries, which represent a rich environment of economic wealth and a high level of income.

Specifically, this study helps strengthen the theoretical and applied literature on the effect of the relationship between saving and capital expansion on technological and financial development in the GCC countries for the period of 1990-2019. This study applied panel regression, fixed effect (FE), feasible generalised least squares (FGLS), fully modified ordinary least squares (FMOLS) and dynamic ordinary least squares (DOLS) models to ensure robustness and extract results that would help decision makers understand the sensitivity of saving behaviour and capital expansion in enhancing technological and financial development, especially in light of financial crises, in order to develop alternative plans to mitigate negative economic impacts. Furthermore, VAR Granger causality test, which was run to demonstrate the causal relationships among the study variables.

This paper is organised as follows. After this introduction, the literature review is described in the second section. The third section details the methodology, data and models. The fourth section presents the empirical findings, and the conclusion and policy implications are discussed in the final fifth section.

\section{Literature review}

Theoretical models of financial and technological development will be discussed in this section within the context of diagnosing and analysing the literature on economic growth theory, and the role of saving and capital expansion in financial and technological development will be highlighted. Positive changes in the financial system have an impact on economic growth by mobilising saving and capital expansion. Although studies have examined the relationship between saving, capital expansion and financial growth, the results were mixed. 
This study focused on the following question: How do saving behaviour and capital expansion impact on financial and technological development by GCC countries? How do VAR Granger causality test demonstrate the causal relationships among the study variables? The theoretical answer to these questions explained in these studies which can be divided into two groups. The first group discussed the effects of saving and capital expansion on financial development, while the second group explained the effects of saving and capital expansion on technological development.

\subsection{The effects of saving and capital expansion on financial development}

Many studies have suggested that saving leads to growth, while others have proposed the opposite scenario. According to Romer (1986), Masih and Peters (2010) and Lucas (1988), saving contributes to increases in investments and, therefore, reflects positively on growth and investment capital as a second stage of growth. Ang (2007) and Attanasio et al. (2000) focused on neoclassical growth theory, which points out that saving increases capital and leads to economic growth and saving precede economic growth. This idea was strengthened by other studies. For example, Alguacil et al. (2004) found that highly active saving behaviour increases economic growth and that there is a long-term relationship between domestic saving and investment. Jangili (2011) and Khundrakpam and Ranjan (2010) analysed a cointegration relationship and pointed to an indirect causal relationship through which one seeks to increase saving in order to enhance investments and thus increase economic growth.

Many studies, such as those by Abu (2010), Patra et al. (2017) and Ma and Li (2016), confirmed that there is a long-run relationship between saving and investment in developed countries, as saving is the first step towards eventual conversion to investments, which leads to financial growth.

Other studies found that the relationship between saving, investment and growth depends on different factors or found no relationship between them. For example, Carroll et al. (2000) and Tang and Tan (2014) argued that saving and growth simultaneously depend on the characteristics and wealth of countries. They found that a high level of growth led to a high level of saving, which then contributed to economic development. Odhiambo (2009) found a causal, two-way relationship between saving and economic growth. However, Sothan (2014) did not find a causal relationship between saving and economic growth.

Verma (2007) and Bist and Bista (2018) suggested that there is a negative relationship between saving and economic growth due to a lack of effective coordination between foreign companies to suit local capabilities. Aghion et al. (2016) argued that the use of international cash flows between companies hurts financial markets and impedes economic growth in emerging countries because they do not have the capability to effectively manage the financial markets. Chao et al. (2019) found that country-level differences between regulations, instructions and laws affect saving levels and the nature and shape of investments. Alguacil et al. (2004) indicated that saving leads to financial and economic growth through liquidity instructions that raise saving rates. Furthermore, foreign saving may increase investment and growth (Guterries \& Solimano, 2007). Attanasio et al. (2000) explained that saving heavily leads to positive investment and growth rates. Krieckhaus (2002) found that increasing public saving enhances economic growth through the effect of national investments. 
Recent studies have shown that other indirect factors affect investment and capital. For example, Rehman et al. (2019) indicated that increasing credit in commercial banks led to financial development and that this effect was strengthened through governance and diversification; this phenomenon also involved hedging credit risks, which increased capital adequacy and enhanced investment. Sarker and Khan (2020) used the ARDL model and identified a long-run relationship between GDP and driver of investments. Schotten and Morais (2019) indicated that investment and capital gains increase due to transparency in decision making and lead to a level of protection for organisational goals. Acheampong (2019) pointed out that harmony in financial development occurs through compatibility between foreign capital and developing individual's demand.

A government's preliminary is pool, move and allocate available resources among industrial sectors in order to boost growth. Mason (1988) pointed out that developed countries are having difficulty attracting foreign investments, as they have proven that an increase in saving and investments leads to economic growth; therefore, these countries are not trying to increase the foreign investment sector, especially in light of the possibility of financial crises. Unlike in developing countries, the nature of the impact saving is positive in developed countries, reinforcing the negative relationship between saving and investments on economic and financial growth.

Many studies have focused on accelerating domestic saving to finance accumulated capital and increase income and economic growth. Some studies have found reverse causation between saving and economic growth, such as suggesting that growth precedes saving. For example, Keynesian theory has an opinion on the level of income that determines the amount of savings and that the effect of saving on growth may be exaggerated (Tang \& Tan, 2014). However, the results are mixed as to whether saving leads to growth or growth leads to saving; this relationship depends on the economic life cycle, as shown by Bolarinwa and Obembe (2017).

Some studies have argued that growth comes first and leads to an increase in saving. For example, Narayan and Narayan (2006), Abu (2010), argued that economic growth leads to saving growth in developed countries. Using the vector error correction (VEC) model, Saltz (1999) demonstrated that higher growth leads to increased saving; however, saving depends on the nature of the country's available resources and the level of income, which enhances consumption and increases the rate of saving. Katircioglu and Nartaliyeva (2006) and Anoruo and Ahmad (2001) stated that there is a directional trend from economic growth to the domestic saving rate. Country-level differences in the relationship between saving and growth are based on income heterogeneity. Mohan (2006) explained that high income countries have a causality from economic growth to saving rate growth, confirming the results of Misztal (2011), who found that causality between saving and growth differed between countries based on the level of GDP.

\subsection{The effects of saving and capital expansion on technological development}

Banks are where savings are retained, which they try to extend in the form of investment credit loans to clients. Bank-related saving also helps strengthen the capital markets through which all financial systems are mobilised, and capital market development enhances technological progress in several ways. First, adaptation to technology requires a large amount 
of capital, which can be easily used in financial systems. Hicks (1969) confirmed that industrial revolutions bring capital and that industrial advancements occur through technology. He noted that adapting to technology requires a certain level of liquid capital investments. Financial markets lead to technology-related risks for investors. Hicks (1969) pointed out, however, that most technological innovations took place before the industrial revolution and that the adaptation and implementation of technology in industries require liquidity and sufficient capital for a long-term contract. Therefore, the technological progress of countries and the extent to which financial systems are strengthened and move within the various economic units in the country are closely related. Second, the appropriate development of financial markets encourages adaptation to produce technological products that reduce investors' liquidity risks (e.g., Bencivenga et al., 1995; Bencivenga \& Smith, 1991; Greenwood \& Jovanovic, 1990).

Although financial systems include liquidity risks for investors, which require long-term financing, they simultaneously enhance the real growth of financial intermediaries through the availability of productive means (Bencivenga \& Smith, 1991). Banks work in concert with customers, allowing high-risk customers to keep a certain percentage of deposits as savings instead of liquid and unproductive assets, which increases the money available for productive capital. Banks also work to eliminate self-financed capital investments and prevent the unnecessary liquidation of capital by large investors due to liquidity.

The main implication of capital expansion methods (e.g., Hicks, 1969) and the pooling functions of risk (e.g., Hicks, 1969; Saint-Paul, 1992; Greenwood \& Jovanovic, 1990; Bencivenga et al., 1995; Bencivenga \& Smith, 1991) of financial markets and institutions should be positively related to the growth of production and enhance technological progress based on technical innovation and adoption. In a cross section of countries, Menéndez et al. (2021) found a positive relationship between measures of financial development and innovation in technological progress through the availability of capital. Companies are also expected to work on external financing in order to benefit from financial development when financing the technology required for growth (Alcaide et al., 2021).

The current study explains the relationship between capital expansion as an input for investment and saving behaviour in terms of technological and financial development. The current study focuses on GCC countries, which tend to have high incomes, and it can be considered one of the first studies in this region. Also, the current study is different from previous studies because it comprehensively examines the effects of two dimensions - saving and investment behaviour - on two closed relationships: technological and financial development.

\section{Methodology}

This section explains the econometric model data specification based on the equations used in the current study.

\subsection{Econometric model data specification}

The panel data used for this study covered a period from 1990 to 2019, and the variables were collected from World Development Indicators (World Bank, 2019). This study examined 
saving, capital expansion and financial and technological development in three GCC countries: Bahrain, Oman and Saudi Arabia. Kuwait, the United Arab Emirates and Qatar were excluded because complete data was unavailable for the study period. Two proxies were used for the independent variables; the saving proxy was measured by adjusted gross domestic saving using the GINI index (LOGADIS), and the capital expansion proxy was measured by gross fixed capital formation (annual \% growth) (GFCF), which reflected accumulated investment. The study used four control variables: real GDP per capita, as measured by GDP per capita growth (annual \%) (RGDP); inflation, as indicated by inflation, consumer prices (annual \%) (CPI); national income as measured by adjusted net national income per capita (annual \% growth) (ANNI); Foreign trade as measured by foreign direct investment, net inflows (\% of GDP) (FDIG).The financial development proxy was used as a dependent variable and measured by the Stocks traded, total value (\% of GDP) (LOGSTTV) and by technological development, as indicated by Individuals using the Internet (\% of population) (LOGIUTI). All variable definitions are available in Appendix A.

The 30-year time period of the study and the exclusion of three GCC countries are considered limitations. However, the time period under study was very important for the GCC countries since it corresponds to economic growth in most of their institutions. The findings highlight the role of the regional economic situation in the GCC in stimulating financial and technological development.

The model used this study was organised based on the following equation:

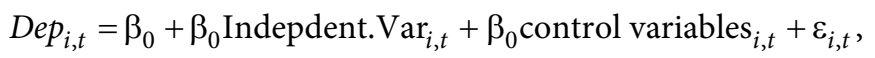

where $D e p_{i, t}$ refers to LOGSTTV ${ }_{\mathrm{t}}$ as the financial development proxy and LOGIUTI $_{i t}$ as the technological development proxy of country I at time $t$; both variables are considered dependent variables. The Indepdent. $\operatorname{Var}_{i, t}$ are the proxies of the saving and capital expansion

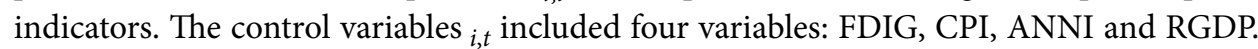

To produce robust results, the methodology described the data in a number of ways and applied various tests, including descriptive statistics; a correlation matrix; augmented Im-Pesaran-Shin (IPS) and Levin-Lin-Chu (LLC) unit root tests; the Pesaran cross-sectional dependence (CD) test; the Padroni, Kao and Johansen Fisher panel cointegration tests; and the panel least squares (PLS), fixed effect (FE), feasible general least squares (FGLS) regression, and fully modified ordinary least squares (FMOLS). and dynamic ordinary least squares (DOLS) models. Diagnostic tests, such as the Breusch-Pagan (B-P) LM test of independence, Pesaran's test of cross-sectional independence, the modified Wald test for groupwise heteroskedasticity, the Wooldridge test for autocorrelation, the Hausman test and the vector autoregressive (VAR) Granger causality test with block exogeneity Wald tests were also used in this study.

The selected variables were based on the economic theory that saving may cause investment and increase financial and technological development. Two proxies were used to decide whether saving led to growth while simultaneously examining the effect of capital expansion on growth and the same argument for the technological development proxy. GCC countries were studied because this is an important region with a wealth of oil and gas, which encourages a good deal of investment. 
The study used cross-sectional and time series panel data (De Hoyos \& Sarafidis, 2006) to minimise the multicollinearity issue by increasing parameters and managed the endogeneity issue through intertemporal dynamics, the individuality of the entities and the degree of freedom (Hsiao, 2007). According to the high number of observations used based on the time and country countries, the panel data was able to manage the heterogeneity (the microunit) (Baltagi, 2008).

Panel unit root tests were used to check the stationary properties of the variables. The study applied the IPS $(1997,2003)$ test; this method allows information from cross-sectional and time series dimensions to be combined. The IPS test assumes a linear trend for each of the $\mathrm{N}$ cross-sectional units, supposes that $s_{i} S(I=1 \ldots, 2 \ldots, N)$ denotes the t-statistics for testing unit roots and lets $\mathrm{E}\left(s_{i} S\right)=\mu$ and $v\left(s_{i} S\right)=\sigma^{2}$. The LLC unit root test was used for more robustness. This estimator showed the main model of the unit root test as follows: $\Delta q_{i t}=$ $z_{i} q_{i, t-1}+\sum_{i=1}^{z_{i}} \varphi,{ }_{i, 1} \Delta y_{i, t-1}+\alpha_{i} d_{i t}+\varepsilon_{i t,}$ where $d_{i t}$ were the deterministic components. $z_{i}=0$ means the $q$ process has a unit root for individual $i$, while $z_{i}<0$ means that the process is stationary around the deterministic component. The LLC unit root test showed that the zi results were identical and negative.

Then, the Pedroni (1999) panel cointegration test was used to examine the effect of the long-run relationship between LOGADIS and LOGGFCF on LOGDC and LOGMHTE. However, the long-run relationship between the variables was tested by three panel cointegration estimations: Pedroni (1999, 2004), Kao (1999) and Johansen Fisher panel cointegration (Johansen, 1988). The Pedroni panel cointegration test was classified based on eleven test statistics (within-dimension and between-dimension (group) tests). The Kao cointegration test (1999) presented the cross-section coefficients and intercepts' homogeneous. Johansen Fisher panel cointegration is a combined test that shows the results of individual independent tests as a test of the full panel (Maddala \& Wu, 1999).

PLS was used as the first step in hypothesis testing for the present study. PLS assumes that data behaviour is the same in different periods. This technique ignores the possible group structure of the data.

FE and random effects (RE) were used to overcome the main problems with panel data, namely, heterogeneity and endogeneity (Wooldridge, 2010). Based on the results of the Hausman test, FE was selected as the most appropriate method for this study (Johnston \& Dinardo, 1997). FE explained the regression model as the group was considered non-random. In a FE test, each group mean is a group-specific fixed quantity. The FE test refers to coefficients in the regression estimator conducted with FE (one time-invariant intercept for each subject). No cross-sectional dependence was found in the data presented in the studied models based on the B-P LM test of independence and the Pesaran CD test, which is applied to test whether the residuals are correlated across entities. However, FE showed the presence of heteroskedasticity and serial correlation in the data based on a modified Wald test for groupwise heteroskedasticity and the Wooldridge test for autocorrelation, respectively.

The FGLS regression estimator was used due to the bias of the PLS estimator and to remove the heteroskedasticity and autocorrelation problems in all of the study models. This estimator supposes that a finite set of parameters refers to $\Omega$ and assumes that $\alpha$ and $\Omega$ 
are known. However, since the FGLS estimator consistent with $\alpha$ is available under ${ }^{\wedge} \alpha$, we changed $\Omega$ to $\Omega=\Omega\left({ }^{\wedge} \wedge\right)$ to apply FGLS.

To overcome the endogeneity issue and serial correlation issues for the panel data of the variables, we used FMOLS according to Kao and Chiang (2000). This test reflects optimal cointegration. Kernel and asymptotic distributions were both included for FMOLS. DOLS was applied to show the short- and long-run relationships. DOLS shows the effect of endogenous variables on exogenous variables, while the explanatory variables conduct the lags, leads and levels (Stock \& Watson, 1993). Furthermore, Granger causality tests were used; these tests show the direction of causality between corruption variables and can apply to the optimal lag length (Jones, 1989).

\section{Empirical results, diagnostic tests and discussion}

The following nine subsections describe how the study hypotheses were tested.

\subsection{Descriptive statistics and discussion}

Table 1 describes 90 observations of the eight variables in the main model over the period of 1990-2019 for the three selected GCC countries and the mean, median, the Jarque-Bera $(\mathrm{J}-\mathrm{B})$, maximum and minimum for the described variables.

Table 1. Descritive statistics

\begin{tabular}{|l|c|c|c|c|c|c|c|c|}
\hline & LOGADIS & GFCF & RGDP & CPI & ANNI & FDIG & LOGSTTV & LOGIUTI \\
\hline Mean & 1.384087 & 3.269420 & 0.488438 & 1.699887 & 0.327106 & 3.158108 & 0.863004 & 0.822971 \\
\hline Median & 1.449845 & 1.533427 & 0.235370 & 1.308601 & -0.347173 & 1.624758 & 0.840421 & 1.199702 \\
\hline Maximum & 1.714651 & 37.70331 & 11.31266 & 12.37541 & 28.53351 & 33.56602 & 2.570846 & 1.998702 \\
\hline Minimum & 0.175759 & -29.44377 & -5.722962 & -2.093333 & -18.52795 & -5.288191 & -0.265553 & -1.678689 \\
\hline Std. Dev. & 0.245028 & 13.32997 & 3.520950 & 2.250847 & 7.660121 & 4.926321 & 0.621912 & 1.082664 \\
\hline Skewness & -1.595718 & 0.440121 & 0.840447 & 1.761070 & 0.446822 & 3.236441 & 0.713632 & -0.690129 \\
\hline Kurtosis & 7.942424 & 2.990540 & 4.116093 & 8.674157 & 4.287341 & 18.55638 & 2.963020 & 2.219241 \\
\hline Jarque-Bera & 129.7981 & 2.905932 & 15.26651 & 167.2557 & 9.209427 & 1064.622 & 7.644193 & 9.430107 \\
\hline Probability & 0.000000 & 0.233876 & 0.000484 & 0.000000 & 0.010005 & 0.000000 & 0.021882 & 0.008959 \\
\hline Sum & 124.5678 & 294.2478 & 43.95944 & 152.9898 & 29.43954 & 284.2297 & 77.67032 & 74.06738 \\
\hline Sum Sq. Dev. & 5.343440 & 15814.23 & 1103.341 & 450.9018 & 5222.293 & 2159.909 & 34.42294 & 104.3224 \\
\hline Observations & 90 & 90 & 90 & 90 & 90 & 90 & 90 & 90 \\
\hline
\end{tabular}

Note: Data created based on WDI reports from 1990-2019.

\subsection{Average annual growth of variables from 1990 to 2019}

Figure 1 shows the average of the dependent and independent variables over the period of 1990-2019 for the selected GCC countries. LOGADIS, LOGSTTV and IUTI fluctuated in fixed value during the study period. GFCF showed an increase from 2002 until 2009, decline due to the financial increase, after this period started to steady increase until 2019. 


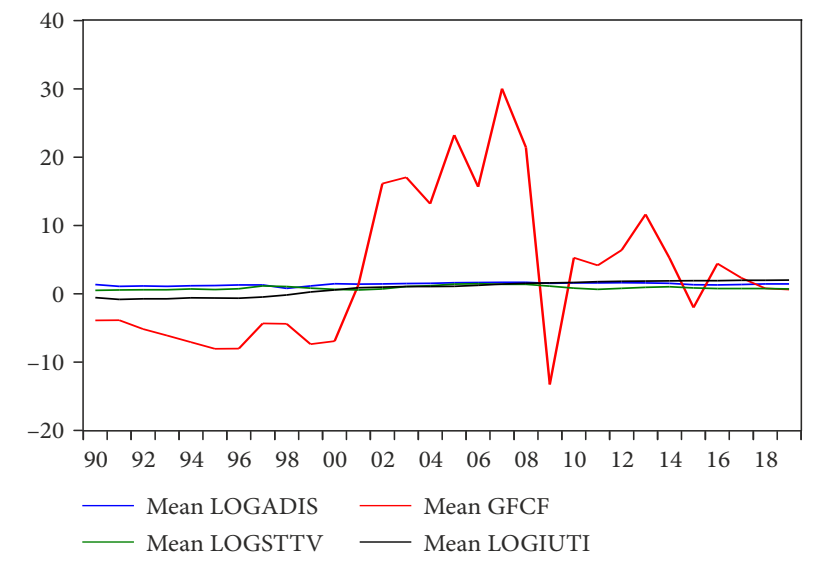

Figure 1. Dependent and independent variables of GCC countries

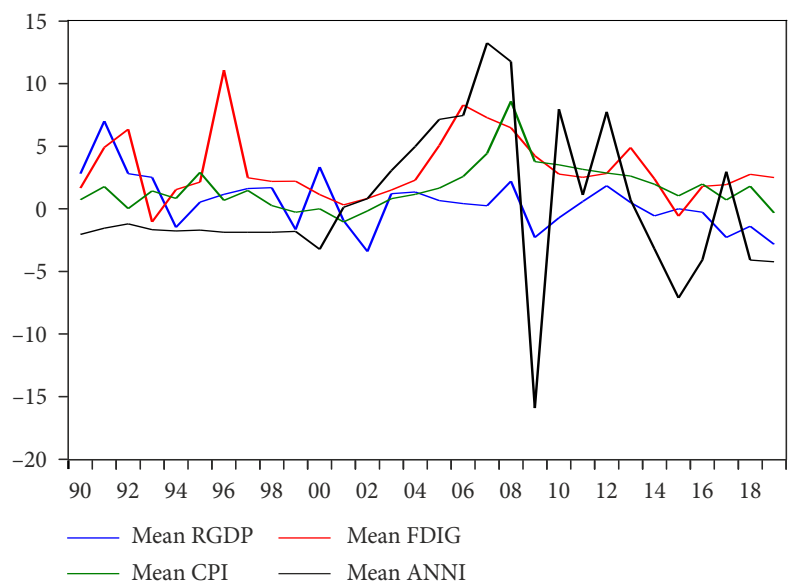

Figure 2. Control variables of GCC countries

Figure 2 shows the control variables, which determine the relationship between saving, capital expansion on financial and technological development. CPI, FDIG and RGDP were fluctuated over the study period from 1990 until 2019. ANNI was below the all-variables lines and the period from 2007-2009 was showed a decline line due to the financial crises, then after 2010 the curve starts to increase.

\subsection{Correlation matrix and discussion}

A correlation matrix was applied for all variables to show the correlation coefficients among the set of regressors and the significant variables. Table 2 shows negative relationships between LOGADIS and RGDP (-0.160519), while the other variables show a positive relationship between LOGADIS and GFCF (0.549118), CPI (0.343934), ANNI (0.305494), FDIG (0.084223), LOGSTTV (0.304852) and LOGIUTI (0.538890) The results for the other proxy, GFCF, were the same as those for LOGADIS except the positive relationships between GFCF 
Table 2. Correlation matrix

\begin{tabular}{|l|c|c|c|c|c|c|c|c|}
\hline Probability & LOGADIS & GFCF & RGDP & CPI & ANNI & FDIG & LOGSTTV & LOGIUTI \\
\hline LOGADIS & 1.000000 & & & & & & & \\
\hline \multirow{2}{*}{ GFCF } & 0.549118 & 1.000000 & & & & & & \\
& 0.0000 & - & & & & & & \\
\hline \multirow{2}{*}{ RGDP } & -0.160519 & 0.026117 & 1.000000 & & & & & \\
& 0.1307 & 0.8070 & - & & & & & \\
\hline \multirow{2}{*}{ CPI } & 0.343934 & 0.315954 & 0.251057 & 1.000000 & & & & \\
\cline { 2 - 10 } & 0.0009 & 0.0024 & 0.0170 & - & & & & \\
\hline \multirow{2}{*}{ ANNI } & 0.305494 & 0.479818 & 0.229773 & 0.337766 & 1.000000 & & & \\
\cline { 2 - 10 } & 0.0034 & 0.0000 & 0.0294 & 0.0011 & - & & & \\
\hline \multirow{2}{*}{ FDIG } & 0.084223 & 0.138428 & 0.063103 & 0.117723 & 0.032687 & 1.000000 & & \\
\cline { 2 - 10 } & 0.4300 & 0.1932 & 0.5546 & 0.2691 & 0.7597 & - & & \\
\hline \multirow{2}{*}{ LOGSTTV } & 0.304852 & 0.316460 & 0.094393 & 0.258432 & 0.204361 & -0.069926 & 1.000000 & \\
\cline { 2 - 9 } & 0.0035 & 0.0024 & 0.3762 & 0.0139 & 0.0533 & 0.5125 & - & \\
\hline \multirow{2}{*}{ LOGIUTI } & 0.538890 & 0.325684 & -0.286635 & 0.213694 & 0.122244 & 0.062118 & 0.053060 & 1.000000 \\
\cline { 2 - 9 } & 0.0000 & 0.0017 & 0.0062 & 0.0431 & 0.2510 & 0.5608 & 0.6194 & - \\
\hline
\end{tabular}

Note: The data summarized from WDI reports from 1990-2019. The table shows the coefficient and significant of variables.

and RGDP (0.026117). The results are consistent with economic theory, and the values of significance are shown in Table 2 . These findings showed that the model was fit to run as most of the coefficients were less than $50 \%$, which indicated that there was no multicollinearity between "predictor and response" as two variables (Evans, 1996).

\subsection{Unit root test and discussion}

Table 3 shows the results of the IPS and LLC unit root tests, which checked the stationarity of the variables. The variables were integrated of order one, I (0), rejecting the null hypothesis of the unit root. Based on these results, all variables were considered stationary at the level.

Table 3. Panel unit root IPS test and LLC test

\begin{tabular}{|l|c|c|c|c|c|c|c|c|}
\hline & LOGADIS & GFCF & RGDP & CPI & ANNI & FDIG & LOGSTTV & LOGIUTI \\
\hline IPS (Level) & $-1.469^{*}$ & $-3.055^{* * *}$ & $-4.578^{* * *}$ & $-2.712^{* * *}$ & $-5.370^{* * *}$ & $-3.307^{* * *}$ & $-2.074^{* *}$ & $-2.097^{* *}$ \\
\hline LLC test t (Level) & $-1.711^{* *}$ & $-3.002^{* * *}$ & $-4.806^{* *}$ & $-2.671^{* * *}$ & $-5.260^{* * *}$ & $-3.046^{* *}$ & $-2.068^{* *}$ & $-5.266^{* * *}$ \\
\hline
\end{tabular}

Note: The significance levels refer to $\mathrm{p}<0.01\left(^{* * *}\right), \mathrm{p}<0.05\left(^{* *}\right)$ and $\mathrm{p}<0.1\left(^{\star}\right)$.

\subsection{Padroni, Kao and Johansen Fisher panel cointegration tests and discussion}

Table 4 shows three cointegration test results that suppose heterogeneity in panels using residuals based on Pedroni's (1999, 2004), Kao (1999) and Johansen Fisher panel cointegration tests. For the first dependent variable proxy, LOGSTTV, we applied the Pedroni (2004) panel cointegration test, which was run based on the lag-based Schwartz information criterion 
Table 4. Padroni, Kao and Johansen Fisher panel cointegration test

\begin{tabular}{|c|c|c|c|c|c|c|c|}
\hline \multicolumn{8}{|c|}{ Padroni panel cointegration test - Dep. Var. LOGSTTV } \\
\hline \multicolumn{5}{|c|}{$\begin{array}{l}\text { Alternative hypothesis: common AR coefs. } \\
\text { (within-dimension)- }\end{array}$} & \multicolumn{3}{|c|}{$\begin{array}{l}\text { Alternative hypothesis: individual AR } \\
\text { coefs. (Group - between-dimension) }\end{array}$} \\
\hline \multirow{2}{*}{ Panel } & \multirow{2}{*}{ Statistic } & \multirow{2}{*}{ Prob. } & \multicolumn{2}{|c|}{ Weighted } & & \multirow{2}{*}{ Statistic } & \multirow{2}{*}{ Prob. } \\
\hline & & & Statistic & Prob. & & & \\
\hline v-Statistic & -1.428292 & 0.9234 & -1.352608 & 0.9119 & Group rho-Statistic & 1.333473 & 0.9088 \\
\hline rho-Statistic & 0.456212 & 0.6759 & 0.748722 & 0.7730 & Group PP-Statistic & -1.301560 & 0.0965 \\
\hline PP-Statistic & -2.112530 & 0.0173 & -1.364839 & 0.0862 & Group ADF-Statistic & -1.343845 & 0.0895 \\
\hline ADF-Statistic & -2.204057 & 0.0138 & -1.450704 & 0.0734 & & & \\
\hline \multicolumn{8}{|c|}{ Padroni panel cointegration test - Dep. Var. LOGIUTI } \\
\hline v-Statistic & -1.193346 & 0.8836 & -0.850029 & 0.8023 & Group rho-Statistic & 0.905773 & 0.8175 \\
\hline rho-Statistic & 0.459792 & 0.6772 & 0.340943 & 0.6334 & Group PP-Statistic & -2.501448 & 0.0062 \\
\hline PP-Statistic & -2.248548 & 0.0123 & -2.315210 & 0.0103 & Group ADF-Statistic & -2.494786 & 0.0063 \\
\hline ADF-Statistic & -2.327887 & 0.0100 & -2.375498 & 0.0088 & & & \\
\hline \multicolumn{8}{|c|}{ Johansen Fisher Panel Cointegration Test- Dep. Var. LOGIUTI } \\
\hline $\begin{array}{l}\text { Hypothesized } \\
\text { No. of CE(s) }\end{array}$ & $\begin{array}{c}\text { Fisher Stat. } \\
\text { (from trace } \\
\text { test) }\end{array}$ & Prob. & $\begin{array}{r}\text { Fisher } \\
\text { (from max }\end{array}$ & $\begin{array}{l}\text { at. } \\
\text { gen test) }\end{array}$ & $\operatorname{Pr}$ & & \\
\hline None & 101.5 & 0.0000 & 39 & & & 00 & \\
\hline At most 1 & 72.48 & 0.0000 & 36 & & & 00 & \\
\hline At most 2 & 41.75 & 0.0000 & 28 & & 0.0 & 001 & \\
\hline At most 3 & 18.45 & 0.0052 & 10 & & & 938 & \\
\hline At most 4 & 12.96 & 0.0437 & 6.8 & & 0.3 & 390 & \\
\hline At most 5 & 10.30 & 0.1126 & 5.2 & & 0.5 & 181 & \\
\hline At most 6 & 15.09 & 0.0196 & 15 & & & 196 & \\
\hline \multicolumn{8}{|c|}{ Johansen Fisher Panel Cointegration Test- Dep. Var. LOGSTTV } \\
\hline None & 91.58 & 0.0000 & 49 & & 0.0 & 000 & \\
\hline At most 1 & 51.27 & 0.0000 & 33 & & & 000 & \\
\hline At most 2 & 23.97 & 0.0005 & 17 & & 0.0 & 82 & \\
\hline At most 3 & 11.27 & 0.0802 & 14 & & 0.0 & 277 & \\
\hline At most 4 & 2.250 & 0.8953 & 0.4 & & & 980 & \\
\hline At most 5 & 5.488 & 0.4830 & 2.7 & & 0.8 & 435 & \\
\hline At most 6 & 13.49 & 0.0359 & 13 & & & 359 & \\
\hline \multicolumn{8}{|c|}{ Kao Residual Cointegration Test- Dep. Var. LOGIUTI } \\
\hline \multicolumn{2}{|c|}{ t-Statistic } & \multicolumn{3}{|c|}{ Prob. } & \multicolumn{3}{|c|}{ Tests } \\
\hline \multicolumn{2}{|c|}{-2.546725} & \multicolumn{3}{|c|}{0.0054} & \multicolumn{3}{|c|}{ Augmented Dickey-Fuller (ADF) } \\
\hline \multicolumn{2}{|c|}{0.037607} & & & & \multicolumn{3}{|l|}{ Residual variance } \\
\hline \multicolumn{2}{|c|}{0.006016} & & & & HAC variance & & \\
\hline \multicolumn{8}{|c|}{ Kao Residual Cointegration Test- Dep. Var. LOGSTTV } \\
\hline \multicolumn{2}{|c|}{-2.037776} & \multicolumn{3}{|c|}{0.0208} & \multicolumn{3}{|c|}{ Augmented Dickey-Fuller (ADF) } \\
\hline 0.03 & 21 & & & & Residual variance & & \\
\hline 0.00 & 256 & & & & HAC variance & & \\
\hline
\end{tabular}

Note: Panel cointegration results based on lag-based Schwartz information criterion (SIC). 
(SIC) (Schwarz, 1978). Six out of the eleven values were significant. The null hypothesis of no cointegration was rejected, and the long-run relationship between the variables at the 5\% and $10 \%$ significance levels was confirmed. For more robustness, we applied the Johansen Fisher panel cointegration test, and the findings also confirmed that there was a long-run relationship and cointegration between the variables.

For the second dependent variable proxy, LOGIUTI, we applied the Kao panel cointegration test. The null hypothesis of no cointegration was rejected at the $1 \%$ and $5 \%$ significance level, and the long-run relationship between the variables was confirmed. The Johansen Fisher panel cointegration test also confirmed this result.

\subsection{Panel least squares, FE and FGLS regression and discussion}

PLS was used for the two models of study (LOGSTTV and LOGIUTI), and the results are presented in Table 5. The results with the first proxy, LOGADIS, showed an in insignificant positive relationship between LOGADIS and GFCF on LOGSTTV and all variables. The results with the second proxy, LOGIUTI, showed a positive relationship between LOGADIS and IUTI. A $1 \%$ increase in LOGADIS led to a 1.894 increase in LOGIUTI. Meanwhile, there was a significant negative relationship between RGDP and LOGIUTI. A 1\% increase in RGDP led to a -0.074 decrease in LOGIUTI.

To overcome the heterogeneity issue of the panel data, we applied FE based on the significant probability of the Hausman test. The FE results of LOGIUTI of model 4 confirmed the PLS results for the second model of LOGIUTI. The FE results with the second proxy, LOGSTTV, showed a positive relationship between GFCF and LOGSSTV. A 1\% increase in GFCF led to a .008 increase in LOGSTTV. The same results for control variables, showed a positive relationship between CPI, FDIG and LOGSSTV. A 1\% increase in CPI and FDIG led to a .031 and .016 increase in LOGSTTV respectively. Although the models showed no heteroscedastic issue, meanwhile there is a problem of serial correlation, we applied the FGLS estimator to overcome this problem, and the findings of LOGSTTV of FGLS confirmed the PLS results while the LOGIUTI confirmed the PLS and FE results.

These results are consistent with economic theory, which points out that a decrease in saving behaviour leads to an increase in investments, which is positively reflected in an increase in financial development in the GCC countries. This situation explains the intensification of investment behaviour by the public in increasing investment projects and the amount being saved so that they are all reflected in the market in the form of investments. In contrast, an increase in technological development requires an increase in saving, which is reflected negatively in the reduction of investments and explains why a great deal of saving is required to carry out innovative technological projects.

These results were consistent with the findings of some recent studies. For example, Aghion et al. (2016) pointed out that domestic saving does not always influence growth and that emerging countries, such as those in the GCC, need cooperation and partnership between foreign and local investors in a way that allows these countries to benefit from innovations in various projects. Therefore, financial development adapts to saving and investment through foreign investment, which tries to introduce technology as a fundamental variable in financial development. Investors must understand the requirements of local and international environments when making decisions to improve the rate of financial growth. 
Table 5. Panel least squares, fixed-effects and FGLS regression

\begin{tabular}{|c|c|c|c|c|c|c|}
\hline \multirow{3}{*}{ Variables } & Model (1) & Model (2) & Model (3) & Model (4) & Model (5) & Model (6) \\
\hline & \multicolumn{2}{|c|}{ Panel Least Squares } & \multirow{2}{*}{$\begin{array}{l}\text { Fixed-effects } \\
\text { LOGSTTV }\end{array}$} & \multirow{2}{*}{$\begin{array}{c}\begin{array}{c}\text { Fixed-effects- } \\
\text { Driscoll and Kraay } \\
\text { standard errors }\end{array} \\
\text { LOGIUTI }\end{array}$} & \multicolumn{2}{|c|}{ FGLS Regression } \\
\hline & LOGSTTV & LOGIUTI & & & LOGSTTV & LOGIUTI \\
\hline \multirow[t]{2}{*}{ LOGADIS } & 0.463 & $1.894^{\star * \star}$ & 0.05202 & $1.89^{* *}$ & 0.463 & $1.894^{* * *}$ \\
\hline & $(0.325)$ & $(0.501)$ & $(0.1959)$ & $(0.909)$ & $(0.312)$ & $(0.482)$ \\
\hline \multirow[t]{2}{*}{ GFCF } & 0.009 & 0.005 & $0.008^{\star *}$ & 0.005 & 0.009 & 0.005 \\
\hline & $(0.006)$ & $(0.009)$ & $(0.003)$ & $(0.007)$ & $(0.005)$ & $(0.009)$ \\
\hline \multirow[t]{2}{*}{ RGDP } & 0.017 & $-0.074^{* *}$ & 0.001 & $-0.074^{* \star}$ & 0.017 & $-0.074^{* *}$ \\
\hline & $(0.019)$ & $(0.030)$ & $(0.011)$ & $(0.035)$ & $(0.018)$ & $(0.028)$ \\
\hline \multirow[t]{2}{*}{ CPI } & 0.035 & 0.053 & $0.031^{*}$ & 0.053 & 0.035 & 0.053 \\
\hline & $(0.031)$ & $(0.049)$ & $(0.018)$ & $(0.043)$ & $(0.030)$ & $(0.047)$ \\
\hline \multirow[t]{2}{*}{ ANNI } & -0.000 & -0.003 & 0.000 & -0.003 & -0.000 & -0.003 \\
\hline & $(0.009)$ & $(0.015)$ & $(0.005)$ & $(0.014)$ & $(0.009)$ & $(0.014)$ \\
\hline \multirow[t]{2}{*}{ FDIG } & -0.016 & 0.004 & $0.016^{*}$ & 0.004 & -0.016 & 0.004 \\
\hline & $(0.012)$ & $(0.019)$ & $(0.008)$ & $(0.011)$ & $(0.012)$ & $(0.019)$ \\
\hline \multirow[t]{2}{*}{ Constant } & 0.177 & $-1.884^{* * *}$ & 0.657 & -1.884 & 0.177 & $-1.884^{* * *}$ \\
\hline & $(0.043)$ & $(0.675)$ & $(0.263)$ & $(1.278)$ & $(0.420)$ & $(0.648)$ \\
\hline Observations & 90 & 90 & 90 & 90 & 90 & 90 \\
\hline R-squared & 0.167 & 0.345 & 0.252 & 0.345 & & \\
\hline F- Value & 2.781 & 7.307 & 4.55 & 6.52 & & \\
\hline Prob. F & 0.016 & 0.000 & 0.000 & 0.000 & & \\
\hline Wald chi2(6) & & & & & 18.10 & 47.55 \\
\hline Prob > chi 2 & & & & & 0.006 & 0.000 \\
\hline Cross-sections & 3 & 3 & 3 & 3 & 3 & 3 \\
\hline $\begin{array}{l}\text { Pesaran's test of } \\
\text { cross-sectional } \\
\text { independence }\end{array}$ & & & 0.699 & 5.396 & & \\
\hline Prob. & & & 0.4845 & 0.000 & & \\
\hline Root MSE & & & - & 0.906 & & \\
\hline $\begin{array}{l}\text { Modified Wald } \\
\text { test for groupwise } \\
\text { heteroskedasticity } \\
\text {-chi2 (3 }\end{array}$ & & & 1.61 & 7.55 & & \\
\hline Prob. & & & 0.6571 & 0.0563 & & \\
\hline $\begin{array}{l}\text { Wooldridge test } \\
\text { for autocorrelation } \\
\text { - Prob }\end{array}$ & & & 0.0141 & 0.0060 & & \\
\hline Hausman test & & & 0.0252 & 0.0001 & & \\
\hline Panels: & & & & & $\begin{array}{c}\text { homoske- } \\
\text { dastic }\end{array}$ & $\begin{array}{c}\text { homoske- } \\
\text { dastic }\end{array}$ \\
\hline Correlation & & & & & $\begin{array}{l}\text { no autocor- } \\
\text { relation }\end{array}$ & $\begin{array}{l}\text { no autocor- } \\
\text { relation }\end{array}$ \\
\hline
\end{tabular}

Note: The significance levels refer to $\left.\mathrm{p}<0.01\left(^{* *}\right), \mathrm{p}<0.05{ }^{* *}\right)$ and $\mathrm{p}<0.1\left(^{*}\right)$. 
Hence, the GCC countries have not been able to diagnose technological potential as a prerequisite for financial development without foreign investment contributions. These results also confirm those of Sahoo et al. (2001) and Verma (2007). Meanwhile, Carroll et al. (2000) found no relationship between saving and development. Verma (2007) and Bist and Bista (2018) found a negative relationship between saving and economic growth due to a lack of effective coordination between foreign companies that suited local and local capabilities. Misztal (2011) found that saving does not cause economic growth, which depends on the country-level characteristics.

Despite these results, we can conclude that the GCC countries have achieved economic and social growth over the decades and that their economies mainly depend on oil for their income. The GCC countries increased employment and spending in the public sector on infrastructure, health and education, which helped raise the standard of living, and the private sector helped boost growth, especially in non-commercial sectors. However, growth is still incomplete due to the necessity of economic diversification, which is part of the cycle of reducing volatility and uncertainty in the global oil market. The growth also helps create job opportunities in the private sector and increases productivity and sustainable growth. Establishing a non-oil economy has become an urgent need for when oil revenues dwindle. The GCC countries have adopted a number of policies to diversify the economies and achieve a stable, low-inflation economic environment through the provision of a stable climate environment, a strong and effective education sector and an advanced health sector with an innovative technological environment. In recent years, the GCC countries have been working to boost domestic and foreign investment and deepen the financial sector. Furthermore, they have set up national development plans to enhance their human capital and skills.

The GCC countries are considered attractive for investors as they are enjoying increasing growth in the tourism sector in which more brands being introduced. Also, investment is still operating in a joint way between the local and foreign partners so that risks are shared between them. However, economic growth in the GCC countries reached its lowest level in 2017, declining by $0.2 \%$ (World Bank, 2019).

The GCC countries are working on adopting a circular economic model instead of a linear model. The circular economic model includes enhancing the value and productivity of material resources and reducing the leakage of value in order to have a positive economic and environmental impact; this may save $\$ 138$ billion by 2030 , which is equivalent to $1 \%$ of GDP between 2020 and 2030.

Meanwhile, remittances are a source of concern for the GCC countries, and they require thinking about how to attract foreign workers to keep their money in the host countries by providing them with feasible investment benefits. If these remittances are retained in the GCC countries and not sent abroad, they can help enhance investment, reduce poverty and improve the level of education and other productive and service sectors by affecting exchange rates, interest rates, consumption and saving levels. The GCC countries use models in understanding the digital economy in many changing industrial sectors and thus spend a lot of money on digital transformation. Even though the digital transformation is supported by the governments in the GCC countries, there are still some challenges, including a lack of necessary expertise in the local market. 


\subsection{Panel fully modified the least squares and panel dynamic least squares and discussion}

FMOLS and DOLS were used to overcome the endogeneity issue, as the OLS estimator was inconsistent and biased on the cointegrated panel. Table 6 shows the panel FMOLS and DOLS results. The coefficients of the DOLS of the first model showed a significant positive relationship between GFCF and LOGSTTV. A 1\% increase in GFCF led to a 0.025 increase in LOGSTTV. The same results for coefficients of the FMOLS of the second model, showed a significant positive relationship between GFCF and LOGSTTV. A 1\% increase in GFCF led to a 0.014 increase in LOGSTTV. The second proxy of LOGIUTI, showed a significant negative relationship between GFCF and LOGIUTI. A $1 \%$ increase in GFCF led to a -0.111 decrease in LOGIUTI in coefficients of the DOLS. In the coefficients of the FMOLS there was a significant positive relationship between LOGADIS and LOGIUTI. A $1 \%$ increase in LOGADIS led to a 4.458 increase in LOGIUTI. Meanwhile, there was a significant negative relationship between GFCF and LOGIUTI. A $1 \%$ increase in GFCF led to a -0.026 decrease in LOGIUTI.

The control variables showed a significant positive relationship between RGDP, FDIG and LOGSTTV for DOLS models. Meanwhile showed a significant positive relationship between CPI and LOGSTTV and a significant negative relationship between ANNI and LOGSTTV in FMOLS model. The second proxy of LOGIUTI, showed a significant negative relationship between RGDP and LOGIUTI in FMOLS model.

These results were consistent with those of Budha (2012), who found a negative shortterm relationship among saving, investments and GDP. Many studies support the economic

Table 6. DOLS and FMOLS estimators

\begin{tabular}{|c|c|c|c|c|}
\hline & Model (1) & Model (2) & Model (3) & Model (4) \\
\hline & DOLS & FMOLS & DOLS & FMOLS \\
\hline VARIABLES & LOGSTTV & LOGSTTV & LOGIUTI & LOGIUTI \\
\hline \multirow[t]{2}{*}{ LOGADIS } & -0.579 & 0.168 & 4.518 & $4.458^{\star * *}$ \\
\hline & $(0.698)$ & $(0.219)$ & (3.416) & $(0.498)$ \\
\hline \multirow[t]{2}{*}{ GFCF } & $0.025^{\star}$ & $0.014^{\star \star \star}$ & $-0.111^{\star \star \star}$ & $-0.026^{* * *}$ \\
\hline & $(0.014)$ & $(0.003)$ & $(0.035)$ & $(0.009)$ \\
\hline \multirow[t]{2}{*}{ RGDP } & $0.105^{*}$ & -0.001 & -0.126 & $-0.072^{\star * *}$ \\
\hline & $(0.055)$ & $(0.012)$ & $(0.095)$ & $(0.027)$ \\
\hline \multirow[t]{2}{*}{ CPI } & 0.007 & $0.049^{* *}$ & -0.359 & -0.024 \\
\hline & $(0.061)$ & $(0.023)$ & $(0.258)$ & $(0.050)$ \\
\hline \multirow[t]{2}{*}{ ANNI } & 0.008 & $-0.011^{\star *}$ & 0.194 & 0.010 \\
\hline & $(0.030)$ & $(0.005)$ & $(0.159)$ & $(0.013)$ \\
\hline \multirow[t]{2}{*}{ FDIG } & $0.046^{*}$ & -0.001 & -0.116 & -0.018 \\
\hline & $(0.026)$ & $(0.013)$ & (0213) & $(0.030)$ \\
\hline
\end{tabular}

Note: Fixed leads and lags specification (lead $=1, \operatorname{lag}=1)$. The significance levels refer to $\mathrm{p}<0.01\left({ }^{* * *}\right)$, $\mathrm{p}<0.05\left(^{(*}\right)$ and $\mathrm{p}<0.1\left(^{*}\right)$. 
theory; for example, Romer (1986), Lucas (1988), Alguacil et al. (2004), Ang (2007) and Attanasio et al. (2000) found that capital expansion reflects investment and identified a positive relationship between investment and growth. Hicks (1969) confirmed that industrial revolutions bring capital and that the industrial advancements occur through technology. He noted that adapting to technology requires a certain level of liquid capital investments. Furthermore, the growth of financial markets encourages adaptation to produce technological products that reduce investors' liquidity risks (e.g., Bencivenga et al., 1995; Bencivenga \& Smith, 1991; Greenwood \& Jovanovic, 1990).

\subsection{VAR Granger causality tests and discussion}

Table 7 shows the results of the VAR Granger causality test, which was run to demonstrate the causal relationships among the study variables. In this model, we considered that the endogenous variables could be treated as exogeneous. We merged the formulas in all 12 models after changing the dependent variables each time. The findings for LOGSTTV showed bidirectional causality between LOGADIS and LOGSTTV as well as single causal directions from ANNI and LOGSTTV. The second model of LOGIUTI showed single causal directions from LOGIUTI and LOGADIS and showed single causal directions from LOGIUTI and CPI. These results indicate that saving and financial development are mutual states that can depend on each other. In addition, financial development is reflected in wage and salary level improvements. The results also showed that technological development is reflected in government spending, which is consistent with economic theories. Furthermore, capital expansion reflects saving, which increases financial development. Meanwhile, capital enhances technological progress by increasing the saving derived from government expenditures (Greenwood \& Jovanovic, 1990; Bencivenga et al., 1995; Bencivenga \& Smith, 1991).

\subsection{Diagnostic tests}

Many diagnostic tests were used to increase robustness and confirm the fit and appropriateness of the study models. The Hausman test was run to select whether the FE or RE model would be the best choice. Since the probability value was less than 0.05 , FE was selected as an appropriate model for solving the heterogeneity issue with the panel data. Then, Pesaran CD test results was run, and the findings showed no cross dependence for model LOGSTTV as the significance was above $5 \%$ and there is a cross sectional dependence for model LOGIUTI. Due to this problem of cross-sectional dependence, the study used Hoechle (2007) suggests to use Driscoll and Kraay standard errors for fixed effect and used in the study. Furthermore, Although the models showed no heteroscedastic issue in the models of study as the significance was below 5\%. Finally, the Wooldridge test for autocorrelation in the panel data results indicated serial correlation as the significance was below 5\%. To overcome the problems of serial correlation, we used the FGLS estimator, which confirmed that both models were homoscedastic and did not have autocorrelation. Finally, FMOLS and DOLS estimators was applied to overcome the endogeneity problem of the panel data, as these estimators used lead and lag for the variables. 


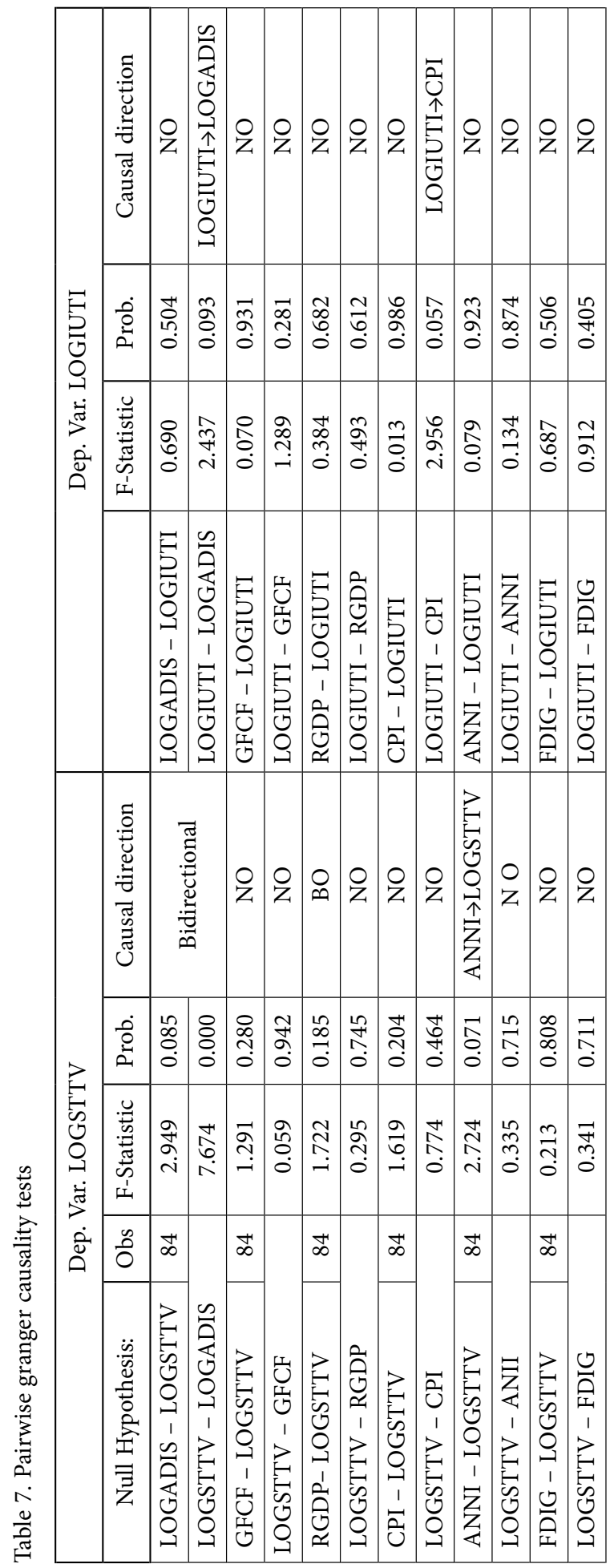




\section{Conclusions and policy implications}

This study analysed the effect of the relationship between saving behaviour and capital expansion on financial and technological development in the three GCC countries during the period of 1990-2019. Various diagnostic tests were used to increase robustness, such as the unit root test; cointegration tests; the PLS, FMOLS and DOLS models; and the VAR Granger causality test.

There was an insignificant negative long-run relationship between saving and financial development in the PLS, FGLS, FMOLS and FE and negative insignificant in DOLS model. Meanwhile, there was a positive long-run relationship between capital expansion and financial development in all models used in this study (PLS, FE, FGLS, DOLS and FMOLS). Conversely, the second proxy showed a significant positive long-run relationship between saving and technological development in the FMOLS, PLS, FE and FGLS models. There was a negative long-run relationship between capital expansion and technological development in the DOLS and FMOLS models. The LOGDC findings showed bidirectional causality between LOGADIS and LOGSTTV and single causal directions from ANNI and LOGSTTV. The LOGIUTI findings showed single causal directions from LOGIUTI and LOGADIS and CPI.

Investment and technological innovation have been considered keys to development. Therefore, the main research question of the present study focused on whether GCC countries need an active investment policy to boost development of the GCC countries. The need for an active investment policy was justified through the presence of external factors for investment and the positive correlation between investment and financial development. The traditional response to adjustment goals includes subsidies and capital taxes, which, in theory, boost growth. Governmental administrative and institutional capacities try to target the right investments, and interaction between the private sector and the public has become a necessity for the achievement of growth.

Based on current findings we can concluded that investment and saving are interdependent and enhance economic development by contributing to the growth of productivity and exports in host countries. The characteristics of the economies of each region are different. For example, the GCC countries are characterised by dependence on oil as a main source of state revenue, and these countries have begun to pay attention to the industrial sector in order to improve financial and technological development through economic diversification. Therefore, it is important to define the characteristics of the host countries, including technological industrial growth and infrastructure, in order to determine the necessity of foreign investment.

Furthermore, the GCC countries depend on foreign workers, which is reflected in their wages, most of which are transferred to their home countries. This requires the GCC countries to provide a flexible investment structure for retaining money and reducing the level of foreign remittances in order to create an attractive investment environment that encourages financial and technological growth. Advantages in local investment attract foreign investment, and the combination of these types of investment creates job opportunities that help transfer administrative and technological skills, all of which contribute to economic development. This phenomenon reinforces the need for an environment that is conducive to investment and contributes to economic development. 
Even if saving is not the main driving force of financial growth, as was proven in the hypothesis on financial development, the hypothesis on technological development strongly indicated the need to provide saving in order to achieve growth. Nevertheless, there must be an adequate level of saving. Therefore, the central policies of countries aim to provide adequate financing for the accumulation of capital and avoid a surplus of investment over saving, which could create inflationary pressures or an imbalance in the balance of payments. Also, encouraging saving may be necessary to expand investment in a framework that contributes to alleviating defects in the capital market and liquidity restrictions on companies. Also, public saving is integrated with individual saving for the purposes of sustainability. Therefore, the GCC country governments must support foreign saving and encourage both public and private sectors to support domestic investment, even if it partially helps with consumption. In addition, there is a need to balance the interest rate between the debtor and the creditor in terms of saving and borrowing money for investment purposes. Meanwhile, easing restrictions on lending leads to a reduction in private saving and interest in reforming the pension system, which has positive effects on local resources.

One limitation of this study is the lack of pre-1990 data on the sample population. Future studies should adopt environmental and social as control variables in order to understand the directionality of relationships in light of continuous improvements in financial, technological and economic growth.

\section{Availability of data and material}

Source of data sets are available in World Bank Indicators from 1990 to 2019, at the link https://data.worldbank.org/

\section{Acknowledgements}

The author would like to thank the editor and anonymous referees for their valuable comments and suggestions to improve the quality of this paper.

\section{References}

Abu, N. (2010). Saving-economic growth nexus in Nigeria, 1970-2007: Granger causality and co-integration analyses. Review of Economic and Business Studies, 5, 93-104. https://econpapers.repec.org/ article/aicrevebs/y_3a2010_3ai_3a5_3aabun.htm

Acheampong, K. (2019). The interaction effect of foreign capital inflows and financial development on economic welfare in sub-Saharan Africa. Financial Innovation, 5, 25.

https://doi.org/10.1186/s40854-019-0139-z

Aghion, P., Comin, D., Howitt, P., \& Tecu, I. (2009). When does domestic saving matter for economic growth? (Working Paper No. 09-080). Harvard Business School. https://doi.org/10.2139/ssrn.1328359

Aghion, P., Comin, D., Howitt, P., \& Tecu, I. (2016). When does domestic savings matter for economic growth? IMF Economic Review, 64(3), 381-407. https://doi.org/10.1057/imfer.2015.41 
Alcaide, A., Guadalajara, N., \& Poza, E. (2021). Modelling IT brand values supplied by consultancy services companies: Empirical evidence for differences. Technological and Economic Development of Economy, 27(1), 120-148. https://doi.org/10.3846/tede.2020.13755

Alguacil, M., Cuadros, A., \& Orts, V. (2004). Does saving really matter for growth? Mexico (19702000). Journal of International Development, 16(2), 281-290. https://doi.org/10.1002/jid.1075

Ang, J. B. (2007). Are saving and investment cointegrated? The case of Malaysia (1965-2003). Applied Economics, 39(17), 2167-2174. https://doi.org/10.1080/00036840600722281

Anoruo, E., \& Ahmad, Y. (2001). Causal relationship between domestic savings and economic growth: Evidence from seven African countries. African Development Review, 13(2), 238-249. https://doi.org/10.1111/1467-8268.00038

Arndt, H. W. (1991). Saving, investment and growth: Recent Asian experience. PNL Quarterly Review, 44(177), 151-162. https://doi.org/10.13133/2037-3643/10648

Attanasio, O. P., Picci, L., \& Scorcu, A. E. (2000). Saving, growth, and investment: A macroeconomic analysis using a panel of countries. The Review of Economics and Statistics, 82(2), 182-211. https://doi.org/10.1162/003465300558731

Baltagi, B. ( 2008). Econometric analysis of panel data (4 ${ }^{\text {th }} \mathrm{ed}$.). John Wiley \& Sons.

Bebczuk, R. N. (2000). Productivity and saving channels of economic growth as latent variables: An application of confirmatory factor analysis. Estudios de Economia, 27(2), 243-257. http://new.econ. uchile.cl/uploads/publicacion/c00bdaed-6a04-4327-ba89-ed919468794e.pdf

Bencivenga, V., \& Smith, B. (1991). Financial intermediation and endogenous growth. Review of Economic Studies, 58(2), 195-209. https://doi.org/10.2307/2297964

Bencivenga, V., Smith, B., \& Starr, R. (1995). Transactions costs, technological choice, and endogenous growth. Journal of Economic Theory, 67(1), 153-177. https://doi.org/10.1006/jeth.1995.1069

Bist, J. P., \& Bista, N. B. (2018). Finance-growth nexus in Nepal: An application of the ARDL approach in the presence of structural breaks. Vikalpa, 43(4), 236-249. https://doi.org/10.1177/0256090918813211

Bodman, P., \& Le, T. (2013). Assessing the roles that absorptive capacity and economic distance play in the foreign direct investment-productivity growth nexus. Applied Economics, 45(3), 1027-1039. https://doi.org/10.1080/00036846.2011.613789

Bolarinwa, S. T., \& Obembe, O. B. (2017). Empirical analysis of the Nexus between saving and economic growth in selected African countries (1981-2014). Journal of Development Policy Practical, 2(1), 110-129. https://doi.org/10.1177/2455133316676420

Budha, B. (2012). A multivariate analysis of savings, investment and growth in Nepal. Munich Personal RePEc Archive. https://mpra.ub.uni-muenchen.de/43346/

Carroll, C. D., Overland, J., \& Weil, D. N. (2000). Saving and growth with habit formation. American Economic Review, 90(3), 341-355. https://doi.org/10.1257/aer.90.3.341

Chao, X., Kou, G., Peng, Y., \& Alsaadi, F. E. (2019). Behavior monitoring methods for trade-based money laundering integrating macro and micro prudential regulation: A case from China. Technological and Economic Development of Economy, 25(6), 1081-1096. https://doi.org/10.3846/tede.2019.9383

Coe, D., \& Helpman, E. (1995). International R\&D spillovers. European Economic Review, 39(5), 859887. https://doi.org/10.1016/0014-2921(94)00100-E

Coe, D., Helpman, E., \& Hoffmaister, A. (1997). North-South R\&D spillovers. The Economic Journal, 107(440), 134-149. https://doi.org/10.1111/1468-0297.00146

De Hoyos, R., \& Sarafidis, V. (2006). Testing for cross-sectional dependence in panel-data models. The Stata Journal, 6(4), 482-496. https://doi.org/10.1177/1536867X0600600403

Dermirguc-Kunt, A. (2006). Finance and economic development: Policy choices for developing countries (Working Paper No. 3955). World Bank. http://documents.worldbank.org/curated/ en/825071468316170479/pdf/wps3955.pdf 
Evans, R. (1996). An analysis of criterion variable reliability in conjoint analysis. Perceptual and Motor Skills, 82(3), 988-990. https://doi.org/10.2466/pms.1996.82.3.988

Greenwood, J., \& Jovanovic, B. (1990). Financial development, growth, and the distribution of income. Journal of Political Economy, 98(5), 1076-1107. https://doi.org/10.1086/261720

Gutiérrez, M., \& Solimano, A. (2007). Savings, investment and growth in the global age: Analytical and policy issues (The AUP Visiting Scholar Working Paper Series, No. 43).

Hansen, H., \& Rand, J. (2006). On the causal links between FDI and growth in developing countries. The World Economy, 29(1), 21-41. https://doi.org/10.1111/j.1467-9701.2006.00756.x

Hicks, R. (1969). A theory of economic history. Clarendon Press.

Hoechle, D. (2007). Robust standard errors for panel regressions with cross-sectional dependence. Stata Journal, 7(3), 281-312. https://doi.org/10.1177/1536867X0700700301

Hsiao, C. (2007). Panel data analysis - advantages and challenges. TEST, 16(1), 1-22. https://doi.org/10.1007/s11749-007-0046-x

Jangili, R. (2011). Causal relationship between saving, investment and economic growth for India - what does the relation imply? https://mpra.ub.uni-muenchen.de/40002/1/MPRA_paper_40002.pdf

Johansen, S. (1988). Statistical analysis of cointegration vectors. Journal of Economic Dynamics and Control, 12(2-3), 231-254. https://doi.org/10.1016/0165-1889(88)90041-3

Johnston, J., \& DiNardo, J. (1997). Econometric methods (4 ${ }^{\text {th }}$ ed.). McGraw-Hill International.

Jones, J. D. (1989). A comparison of lag-length selection techniques in tests of granger causality between money growth and inflation: evidence for the US, 1959-86. Applied Economics, 21(6), 809822. https://doi.org/10.1080/758520275

Kao, C. (1999). Spurious regression and residual-based tests for cointegration in panel data. Journal of Econometrics, 90(1), 1-44. https://doi.org/10.1016/S0304-4076(98)00023-2

Kao, C. C., \& Chiang, M. (2000). On the estimation and inference of a cointegrated regression in panel data. In B. H. Baltagi, T. B. Fomby, \& R. Carter Hill (Eds.), Advances in Econometrics: Vol. 15. Nonstationary panels, panel cointegration, and dynamic panels (pp. 179-222). Emerald Group Publishing Limited. https://doi.org/10.1016/S0731-9053(00)15007-8

Katircioglu, S., \& Nartaliyeva, A. (2006). Foreign direct investment, domestic savings and economic growth in Kazakhstan: Evidence from co-integration and causality tests. Investment Management and Financial Innovations, 3(2), 34-45.

Khundrakpam, J. K., \& Ranjan, R. (2010). Saving-investment nexus and international capital mobility in India: Revisiting Feldstein-Horioka hypothesis. Indian Economic Review, 45(1), 49-66. https://www.jstor.org/stable/29793953

Krieckhaus, J. (2002). Reconceptualizing the developmental state: Public savings and economic growth. World Development, 30(10), 1697-1712. https://doi.org/10.1016/S0305-750X(02)00064-5

Kwark, N.-S., \& Shyn, Y.-S. (2006). International R\&D spillovers revisited: Human capital as an absorptive capacity for foreign technology. International Economic Journal, 20(2), 179-196. https://doi.org/10.1080/10168730600699556

Le, T. (2008). Brain drain or brain circulation: Evidence from OECD's international migration and R\&D spillovers. Scottish Journal of Political Economy, 55(5), 618-636. https://doi.org/10.1111/j.1467-9485.2008.00468.x

Le, T., \& Bodman, P. (2011). Remittances or technological diffusion: Which drives domestic gains from brain drain? Applied Economics, 43(18), 2277-2285. https://doi.org/10.1080/00036840903153838

Lucas, R. E. Jr. (1988). On the mechanics of economic development. Journal of Monetary Economics, 22(1), 3-42. https://doi.org/10.1016/0304-3932(88)90168-7

Ma, W., \& Li, H. (2016). Time-varying saving-investment relationship and the Feldstein-Horioka puzzle. Economic Modelling, 53, 166-178. https://doi.org/10.1016/j.econmod.2015.11.013 
Maddala, G. S. \& Wu, S. (1999). A comparative study of unit root tests with panel data and a new simple test. Oxford Bulletin of Economics and Statistics, 61(51), 631-652. https://doi.org/10.1111/1468-0084.0610s1631

Mankiw, N., Romer, W., \& Weil, D. (1992). A Contribution to the empirics of economics growth. Quarterly Journal of Economics, 107(2), 407-437. https://doi.org/10.2307/2118477

Masih, R., \& Peters, S. (2010). A revisitation of the savings-growth nexus in Mexico. Economics Letters, 107(3), 318-320. https://doi.org/10.1016/j.econlet.2010.02.001

Mason, A. (1988). Saving, economic growth, and demographic change. Population and Development Review, 14(1), 113-144. https://doi.org/10.2307/1972502

Menéndez, R., Martín, A., Candamio, L., \& Álvarez, M. (2021). An enhanced techno-economic analysis of LCOE public incentives vs private investment. Technological and Economic Development of Economy, 27(1), 1-23. https://doi.org/10.3846/tede.2020.11259

Misztal, P. (2011). The relationship between savings and economic growth in countries with different level of economic development. e-Finance: Financial Internet Quarterly, 7(2), 17-29. https://www. econstor.eu/bitstream/10419/66731/1/670173894.pdf

Mohan, R. (2006). Causal relationship between savings and economic growth in countries with different income levels. Economics Bulletin, 5(3), 1-12. https://core.ac.uk/download/pdf/6310268.pdf

Narayan, P. K., \& Narayan, S. (2006). Savings behaviour in Fiji: An empirical assessment using the ARDL approach to co-integration. International Journal of Social Economics, 33(7), 468-480. https://doi.org/10.1108/03068290610673243

Odhiambo, N. M. (2009). Savings and economic growth in South Africa: A multivariate causality test. Journal of Policy Modelling, 31(5), 708-718. https://doi.org/10.1016/j.jpolmod.2009.04.001

Park, J. (2004). International student flows and R\&D spillovers. Economic Letters, 82(3), 315-320. https://doi.org/10.1016/j.econlet.2003.07.012

Patra, S. K., Murthy, D. S., Kuruva, M. B., \& Mohanty, A. (2017). Revisiting the causal nexus between savings and economic growth in India: An empirical analysis. EconomiA, 18(3), 380-391. https://doi.org/10.1016/j.econ.2017.05.001

Pedroni, P. (1999). Critical values for cointegration tests in heterogeneous panels with multiple regressors. Oxford Bulletin of Economics and Statistics, 61(S1), 653-670. https://doi.org/10.1111/1468-0084.61.s1.14

Pedroni, P. (2004). Panel cointegration: Asymptotic and finite sample properties of pooled time series tests with an application to the PPP hypothesis. Econometric Theory, 20(3), 597-625. https://doi.org/10.1017/S0266466604203073

Romer, P. M. (1986). Increasing returns and long-run growth. Journal of Political Economy, 94(5), 1002-1037. https://doi.org/10.1086/261420

Ramsey, F. (1928). A mathematical theory of saving. Economic Journal, 38(152), 543-559. https://doi.org/10.2307/2224098

Rehman, Z., Muhammad, N., Sarwar, B., \& Raz, M. (2019). Impact of risk management strategies on the credit risk faced by commercial banks of Balochistan. Financial Innovation, 5, 44. https://doi.org/10.1186/s40854-019-0159-8

Sahoo, P., Nataraj, G., \& Kamaiah, B. (2001). Savings and economic growth in India: The long run nexus. Savings and Development, 25(1), 67-80.

Saint-Paul, G. (1992). Technological choice, financial markets and economic development. European Economic Review, 36(4), 763-781. https://doi.org/10.1016/0014-2921(92)90056-3

Saltz, I. (1999). An examination of the causal relationship between saving and growth in the third world. Journal of Economics and Finance, 23, 90-98. https://doi.org/10.1007/BF02752690 
Sarker, B., \& Khan, F. (2020). Nexus between foreign direct investment and economic growth in Bangladesh: An augmented autoregressive distributed lag bounds testing approach. Financial Innovation, 6, 10. https://doi.org/10.1186/s40854-019-0164-y

Schotten, P., \& Morais, D. (2019). A group decision model for credit granting in the financial market. Financial Innovation, 5, 6. https://doi.org/10.1186/s40854-019-0126-4

Schwarz, G. (1978). Estimating the dimension of a model. Annals of Statistics, 6(2), 461-464. https://doi.org/10.1214/aos/1176344136

Singh, T. (2010). Does domestic saving cause economic growth? A time-series evidence from India. Journal of Policy Modeling, 32(2), 231-253. https://doi.org/10.1016/j.jpolmod.2009.08.008

Solow, R. M. (1988). Growth theory and after. American Economic Review, 78(3), 307-317. https://www. depfe.unam.mx/doctorado/teorias-crecimiento-desarrollo/solow_1988.pdf

Sothan, S. (2014). Causal relationship between domestic saving and economic growth: Evidence from Cambodia. International Journal of Economics and Finance, 6(9), 213-220. https://doi.org/10.5539/ijef.v6n9p213

Stock, J. H., \& Watson, M. W. (1993). A simple estimator of cointegrating vectors in higher order integrated systems. Econometrica: Journal of the Econometric Society, 61(4), 783-820. https://doi.org/10.2307/2951763

Tang, C. F., \& Tan, B. W. (2014). A revalidation of the savings-growth nexus in Pakistan. Economic Modelling, 36, 370-377. https://doi.org/10.1016/j.econmod.2013.10.012

Verma, R. (2007). Savings, investment and growth in India: An application of the ARDL bounds testing approach. South Asia Economic Journal, 8(1), 87-98. https://doi.org/10.1177/139156140600800105

Wooldridge, J. M. (2010). Econometric analysis of cross section and panel data (2 $2^{\text {nd }} \mathrm{ed}$.). MIT Press.

World Bank. (2019). World development indicators. Retrieved February 1, 2021, from https://databank. worldbank.org/source/worlddevelopment-indicato 


\section{APPENDIX}

Definitions of the Variables (source: World Bank, 2019)

\begin{tabular}{|c|c|c|c|}
\hline Variable & Abbreviations & Measures & Definition \\
\hline $\begin{array}{l}\text { Financial } \\
\text { development }\end{array}$ & LOGSTTV & $\begin{array}{l}\text { Stocks traded, total value } \\
\text { (\% of GDP) }\end{array}$ & $\begin{array}{l}\text { This refers to the value of shares } \\
\text { traded is the values of total } \\
\text { shares included both domestic } \\
\text { and foreign, multiplied by their } \\
\text { respective matching prices. }\end{array}$ \\
\hline $\begin{array}{l}\text { Technological } \\
\text { development }\end{array}$ & LOGIUTI & $\begin{array}{l}\text { Individuals using the } \\
\text { Internet (\% of population) }\end{array}$ & $\begin{array}{l}\text { This refers to an individual who } \\
\text { have used the Internet via a digital } \\
\text { machine. }\end{array}$ \\
\hline $\begin{array}{l}\text { Saving behaviour } \\
\text { proxy }\end{array}$ & LOGADIS & $\begin{array}{l}\text { Adjusted gross domestic } \\
\text { saving using the GINI } \\
\text { index }\end{array}$ & $\begin{array}{l}\text { This refers to the national saving } \\
\text { of the private and public sectors, } \\
\text { which includes tangible and } \\
\text { financial assets that are considered } \\
\text { gross capital formation and a } \\
\text { function of gross domestic saving. } \\
\text { This measure was adjusted using } \\
\text { the GINI index. }\end{array}$ \\
\hline Capital expansion & GFCF & $\begin{array}{l}\text { gross fixed capital } \\
\text { formation (annual \% } \\
\text { growth) }\end{array}$ & $\begin{array}{l}\text { This refers to money that helps } \\
\text { increase investments and profits. } \\
\text { It includes the financing needed } \\
\text { to increase spending and the level } \\
\text { of inventory and fixed and short- } \\
\text { term assets in light of increased } \\
\text { production and marketing costs. }\end{array}$ \\
\hline $\begin{array}{l}\text { Real GDP per } \\
\text { capita }\end{array}$ & RGDP & Real GDP per capita & $\begin{array}{l}\text { This measures the level of income } \\
\text { or the level of GDP for each } \\
\text { individual, adjusted for inflation, } \\
\text { meaning that it measures the real } \\
\text { value of goods and services at } \\
\text { prices outside the inflation range. }\end{array}$ \\
\hline Inflation as CPI & $\mathrm{CPI}$ & Consumer price index & $\begin{array}{l}\text { This is the general rate of prices } \\
\text { for goods and services that are } \\
\text { accounted for by changes in the } \\
\text { basket of goods and services for } \\
\text { the country. }\end{array}$ \\
\hline Foreign Trade & FDIG & $\begin{array}{l}\text { foreign direct investment, } \\
\text { net inflows ( } \% \text { of GDP) }\end{array}$ & $\begin{array}{l}\text { This is the all the equity capital, } \\
\text { long and short run capital, } \\
\text { reinvestment of earnings, as shown } \\
\text { in the balance of payments. }\end{array}$ \\
\hline National Income & ANNI & $\begin{array}{l}\text { adjusted net national } \\
\text { income per capita (annual } \\
\% \text { growth) }\end{array}$ & $\begin{array}{l}\text { This refers to This refer to GNI } \\
\text { minus consumption of fixed capital } \\
\text { and depletion of natural resources. }\end{array}$ \\
\hline
\end{tabular}

